\title{
MOTIVASI KERJA, KEPUASAN KERJA, DAN KOMITMEN ORGANISASIONAL KARYAWAN
}

\author{
Steven Gondokusumo ${ }^{1 *}$ dan Eddy Madiono Sutanto ${ }^{1}$ \\ Program Studi Manajemen, Universitas Kristen Petra \\ Jalan Siwalankerto 121-131, Surabaya 60236, Indonesia \\ *Penulis Korespondensi; Email: meng_fa92@yahoo.com
}

\begin{abstract}
Abstrak
Penelitian ini dilakukan untuk mengetahui pengaruh motivasi kerja dan kepuasan kerja karyawan terhadap komitmen organisasional. Populasi penelitian berjumlah 214 orang karyawan dengan sampel sebanyak 145 karyawan. Penetapan sampel dengan metode judgement sampling. Data dianalisis dengan regresi linier berganda. Hasil penelitian ini menunjukkan bahwa variabel motivasi kerja memiliki pengaruh yang positif dan signifikan terhadap variabel komitmen organisasional. Variabel kepuasan kerja juga memiliki pengaruh yang positif dan signifikan terhadap komitmen organisasional. Variabel motivasi kerja dan kepuasan kerja sama-sama memiliki pengaruh terhadap komitmen organisasional dan didominasi oleh kepuasan kerja. Peningkatan motivasi kerja karyawan diharapkan dapat membantu perusahaan dalam meningkatkan kepuasan kerja karyawan yang secara langsung berpengaruh pada komitmen organisasional karyawan
\end{abstract}

Kata kunci: Motivasi kerja, kepuasan kerja, komitmen organisasional

\begin{abstract}
This study was conducted to determine the effect of work motivation and job satisfaction on organizational commitment. The population amounted to 214 employees and the samples were 145 people. The sampling method was judgment sampling. The analytical method was multiple linear regression. The results indicated that work motivation variable had a positive and significant effect on organizational commitment. Job satisfaction also had a positive and significant influence on organizational commitment. Work motivation and job satisfaction had the same influence on organizational commitment and job satisfaction dominated. The increase in employee motivation was expected to help the company in increasing employee's job satisfaction that directly affected the commitment of employees.
\end{abstract}

Keywords: Work motivation, work satisfaction, organizational commitment

\section{Pendahuluan}

Motivasi merupakan indikator yang membuat seorang pekerja lebih puas dalam menjalankan aktivitasnya. Motivasi kerja dapat menjadi pendorong yang ada dalam diri manusia dan dapat mengarahkan perilakunya untuk melaksanakan tugas dan tanggung jawabnya (Panggalih \& Zulaicha, 2012). Murti dan Srimulyani (2013), yang melakukan penelitian mengenai motivasi kerja pada PDAM di kota Madiun, menemukan bahwa jika kebutuhan karyawan tidak terpenuhi, maka hal itu dapat menjadi suatu motivasi bagi mereka untuk memenuhi kebutuhan tersebut.

Perusahaan yang sukses memerlukan karyawan yang mampu dan mau mengerjakan tugas yang bukan termasuk tugas formal mereka. Karyawan yang memiliki kepuasan kerja memiliki konsep akan hasil, perlakuan, dan prosedur yang adil, sehingga perlu adanya kepercayaan antara karyawan dan atasan, ma- ka karyawan akan dengan sukarela bertindak melebihi harapan organisasi (Sutanto \& Tania, 2013). Secara sederhana kepuasan kerja dapat disimpulkan sebagai apa yang membuat orang-orang menginginkan dan menyenangi pekerjaan karena mereka merasa bahagia dalam melakukan pekerjaannya.

Selain kepuasan kerja dan motivasi kerja yang perlu untuk menjadi perhatian perusahaan, komitmen organisasional juga menjadi aspek yang penting. Komitmen dianggap sangat penting hingga membuat beberapa organisasi memasukkan unsur komitmen sebagai salah satu syarat seseorang untuk memegang jabatan/posisi. Oleh karena itu, penting bagi suatu organisasi/perusahaan untuk mengetahui faktor-faktor yang mempengaruhi komitmen dalam diri karyawan.

Menurut Sutanto dan Tania (2013) komitmen pada organisasi merupakan suatu keadaan, yang mana seorang karyawan memihak pada suatu organisasi dan tujuan-tujuannya, serta berniat memelihara ke- 
anggotaan dalam organisasi itu. Karyawan yang memiliki komitmen terhadap organisasi memiliki potensi untuk memperbaiki kinerja, baik secara individual, kelompok maupun organisasi. Karyawan yang memiliki komitmen organisasional yang tinggi akan memberikan usaha yang maksimal secara sukarela untuk kemajuan organisasi. Mereka akan berusaha mencapai tujuan organisasi dan menjaga nilai-nilai organisasi. Selain itu, mereka akan berpartisipasi dan terlibat aktif untuk memajukan perusahaan. Karyawan yang memiliki komitmen organisasional yang tinggi akan bertanggung jawab dengan bersedia memberikan seluruh kemampuannya karena merasa memiliki organisasi.

Pentingnya penelitian mengenai pengaruh kepuasan kerja terhadap pengembangan komitmen organisasional dalam perusahaan karena pekerja yang puas akan memiliki persepsi positif terhadap organisasi secara keseluruhan. Mathiew and Jones mengatakan bahwa kepuasan kerja dan motivasi kerja sangat berkaitan langsung dengan komitmen organisasional karyawan (dalam Sutanto \& Tania, 2013). Kepuasan kerja terkadang dikaitkan dengan besar kecilnya suatu gaji. Padahal itu kurang tepat. Bukan besar kecilnya suatu gaji atau tinggi rendahnya suatu jabatan yang menentukan suatu kepuasan tetapi harus dilihat dari sudut pandang orang itu sendiri, apakah mereka merasa sudah cukup puas dengan kondisi yang mereka dapatkan sekarang.

Tujuan penelitian ini untuk menguji dan menganalisis pengaruh motivasi kerja terhadap komitmen organisasional, pengaruh kepuasan kerja karyawan terhadap komitmen organisasional, serta pengaruh secara serentak dari motivasi dan kepuasan kerja terhadap komitmen organisasional.

\section{Kerangka Pemikiran}

Penelitian ini dilakukan dengan suatu kerangka pemikiran sebagaimana terlihat dalam Gambar 1.

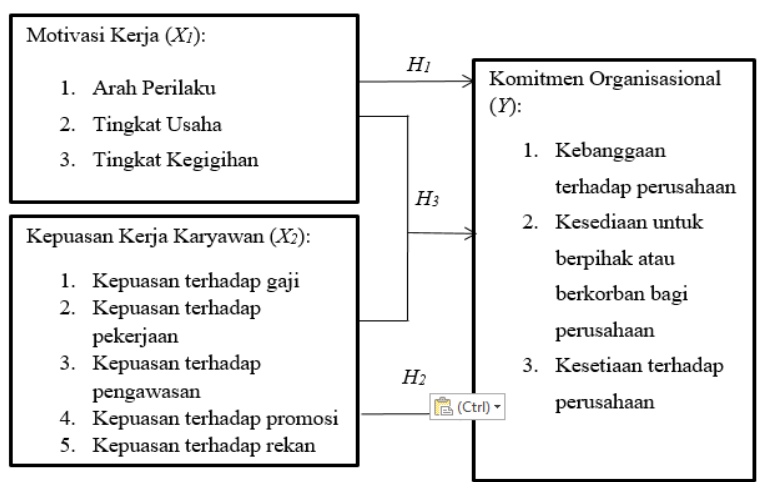

Gambar 1. Kerangka Pemikiran

Sumber: Penggalih dan Zulaicka (2012); Sutanto dan Tania (2013).

\section{Hipotesis}

Berdasarkan hasil penelitian sebelumnya dan kerangka pemikiran, maka ditetapkan beberapa hipotesis penelitian, antara lain $H_{1}$ : motivasi kerja karyawan mempunyai pengaruh positif terhadap komitmen organisasional, $\mathrm{H}_{2}$ : kepuasan kerja karyawan mempunyai pengaruh positif terhadap komitmen organisasional, $H_{3}$ : motivasi kerja karyawan dan kepuasan kerja karyawan mempunyai pengaruh secara serempak dan positif terhadap komitmen organisasional.

\section{Metode Penelitian}

\section{Jenis Penelitian}

Penelitian ini merupakan penelitian kuantitatif eksplanatif yang bertujuan untuk membuktikan hubungan antara variabel independen yaitu motivasi kerja dan kepuasan kerja dengan variabel dependen yaitu komitmen organisasional (Sugiyono, 2011).

\section{Populasi dan Sampel Penelitian}

Populasi dalam penelitian ini yaitu karyawan perusahaan yang merupakan pekerja tetap dan berjumlah 214 orang. Penelitian ini menggunakan nonprobability sampling, yaitu sampel yang dipilih secara arbitrer oleh peneliti. Probabilitas masing-masing anggota populasi tidak diketahui dari non-probability sampling (Kuncoro, 2009). Dalam penelitian ini digunakan teknik judgement sampling, yaitu memilih sampel berdasarkan penilaian terhadap beberapa karakteristik anggota sampel yang disesuaikan dengan maksud penelitian (Kuncoro, 2009). Dari beberapa kriteria yang telah ditentukan, didapatkan sampel dalam penelitian ini yaitu karyawan perusahaan yang bekerja di toko berjumlah 145 orang.

\section{Definisi Operasional Variabel Motivasi Kerja $\left(X_{I}\right)$}

Definisi operasional motivasi kerja dalam penelitian ini yaitu dorongan dari dalam diri karyawan untuk mencapai tujuan tertentu. Indikator yang dipakai untuk mengukur variabel motivasi kerja ialah arah perilaku (direction of behavior), tingkat usaha (level of effort), tingkat kegigihan (level of persistence).

\section{Definisi Operasional Variabel Kepuasan Kerja $\left(X_{2}\right)$}

Definisi operasional kepuasan kerja dalam penelitian ini yaitu perasaan positif karyawan pada suatu pekerjaan, berupa dampak atau hasil evaluasi dari berbagai aspek pekerjaan tersebut. Indikator yang dipakai 
untuk mengukur variabel kepuasan kerja ialah kepuasan terhadap gaji, kepuasan terhadap pekerjaan, kepuasan terhadap pengawasan, kepuasan terhadap promosi, kepuasan terhadap rekan kerja.

\section{Definisi Operasional Variabel Komitmen Organisasional $(Y)$}

Definisi operasional komitmen organisasional dalam penelitian ini yaitu sikap karyawan yang memiliki keinginan tinggi untuk bekerja dan berkorban bagi perusahaan. Indikator yang dipakai untuk mengukur variabel komitmen organisasional ialah kebanggaan terhadap perusahaan, kesediaan untuk berpihak/ berkorban bagi perusahaan, kesetiaan terhadap perusahaan.

\section{Metode Pengumpulan Data}

Penelitian ini menggunakan metode pengumpulan data melalui kuesioner. Menurut Kuncoro (2009), kuesioner merupakan daftar pernyataan-pernyataan yang disusun secara tertulis. Responden dalam penelitian ini adalah seluruh karyawan perusahaan yang berjumlah 145 orang.

\section{Metode Analisis Data}

Metode analisis data dalam penelitian ini menggunakan analisis statistik deskriptif, uji validitas, uji reliabilitas, uji asumsi klasik, serta dengan menggunakan regresi linier berganda, uji $F$, uji $t$, dan cross tabulation yang akan menggunakan SPSS for Windows Ver. 13.0.

Analisis deksriptif dilakukan untuk memperoleh gambaran secara mendalam dan obyektif mengenai objek penelitian. Analisis deskriptif menggunakan alat ukur, yaitu mean. Analisis rata-rata/mean digunakan untuk mengetahui frekuensi rata-rata jawaban dari responden terhadap masing-masing pernyataan pada tiap total variabel maupun pada tiap dimensi dari variabel tersebut.

Uji validitas dalam penelitian ini dilakukan untuk menguji ketepatan item-item pernyataan kuesioner dalam mengukur variabel penelitian. Teknik yang digunakan adalah korelasi pearson product moment. Suatu item pernyataan dinyatakan valid jika korelasi product moment pearson menghasilkan nilai signifikansi $(\alpha)<0,05$ (Kuncoro, 2009).

Uji reliabilitas dalam penelitian ini dilakukan untuk menguji kehandalan kuesioner dalam mengukur variabel penelitian dengan menghasilkan pengukuran yang konsisten. Teknik yang digunakan adalah uji Cronbach's Alpha. Item-item pernyataan dalam ang- ket dinyatakan reliabel jika nilai Cronbach's Alpha $>0,6$ (Ghozali, 2012).

Uji asumsi dalam penelitian ini meliputi uji normalitas, uji multikolinearitas, uji heteroskedastisitas, dan uji autokolerasi. Uji normalitas dilakukan untuk mendeteksi normalitas residual yang dihasilkan model regresi. Regresi yang baik mengansumsikan residual berdistribusi normal (Ghozali, 2012). Uji multikolinieritas dilakukan untuk mendeteksi ada tidaknya korelasi yang kuat antara variabel bebas dalam model regresi. Regresi yang baik mengansumsikan tidak ada multikolinieritas (Ghozali, 2012). Uji heteroskedastisitas dilakukan untuk mendeteksi ada tidaknya ketidakhomogenan ragam antar residual. Regresi yang baik mengansumsikan tidak ada heteroskedastisitas (Ghozali, 2012).

Analisis regresi linier berganda dilakukan untuk menguji pengaruh simultan dari beberapa variabel bebas terhadap satu variabel terikat yang berskala interval (Kuncoro, 2009). Uji $F$ digunakan untuk mengetahui pengaruh secara serempak (simultan) variabel bebas terhadap variabel terikat (Kuncoro, 2009). Uji t digunakan untuk mengetahui pengaruh secara parsial variabel bebas terhadap variabel terikat (Kuncoro, 2009).

Metode cross tabulation dalam penelitian ini digunakan untuk mengidentifikasikan dan mengetahui korelasi antar dua variabel (Kuncoro, 2009). Apabila terdapat hubungan antar keduanya, maka terdapat tingkat ketergantungan yang saling mempengaruhi yaitu perubahan variabel yang satu ikut mempengaruhi perubahan pada variabel lain.

\section{Analisis Data dan Pembahasan}

Perusahaan yang dipakai dalam penelitian ini bergerak dalam bidang jual beli perhiasan yang didirikan pada tahun 1975. Perusahaan banyak mengalami hambatan seperti masih kurang terkenalnya produk perusahaan dan banyaknya pesaing yang sudah ternama. Oleh karena masih belum terkenal, maka perlu adanya usaha yang keras dalam mendapatkan kepercayaan dari konsumen.

Perusahaan ini memiliki competitive advantage dengan memiliki relasi yang cukup baik dengan pabrik-pabrik perhiasan, sehingga perusahaan ini sering mengadakan pameran dengan dukungan pabrik -pabrik ternama. Keuntungan yang nyata dari kerja sama ini adalah perusahaan ini memiliki lebih banyak model perhiasan yang cukup unik dan dapat dibilang masih belum ada di pasaran.

Produk yang dijual oleh perusahaan ini beragam, seperti emas batang, emas 70 karat, emas 75 karat hingga perhiasan yang tidak umum di pasaran (antik). 
Perusahaan ini juga menerima request order dari konsumen yang ingin membuat bentuk perhiasan sesuai selera konsumen. Sampai saat ini perusahaan ini memiliki satu kantor administrasi dan 11 kantor penjualan yang berada di kota Surabaya.

Dalam penelitian ini dijelaskan hasil uji validitas dan reliabilitas angket penelitian untuk memastikan bahwa angket penelitian yang disebar telah valid dan reliabel, sehingga data yang dihasilkan akurat.

Tabel 1

Uji Validitas

\begin{tabular}{|c|c|c|c|c|}
\hline Variabel & Item & $\begin{array}{c}\text { Nilai } \\
\text { Korelasi }\end{array}$ & Sig. & Keterangan \\
\hline \multirow[t]{11}{*}{ Motivasi Kerja $\left(X_{I}\right)$} & $X_{1.1}$ & 0,635 & 0,000 & valid \\
\hline & $X_{1.2}$ & 0,572 & 0,000 & valid \\
\hline & $X_{1.3}$ & 0,694 & 0,000 & valid \\
\hline & $X_{1.4}$ & 0,523 & 0,000 & valid \\
\hline & $X_{1.5}$ & 0,675 & 0,000 & valid \\
\hline & $X_{1.6}$ & 0,680 & 0,000 & valid \\
\hline & $X_{1.7}$ & 0,685 & 0,000 & valid \\
\hline & $X_{1.8}$ & 0,743 & 0,000 & valid \\
\hline & $X_{1.9}$ & 0,613 & 0,000 & valid \\
\hline & $X_{1.10}$ & 0,649 & 0,000 & valid \\
\hline & $X_{1.11}$ & 0,597 & 0,000 & valid \\
\hline \multirow[t]{11}{*}{ Kepuasan Kerja $\left(X_{2}\right)$} & $X_{2.1}$ & 0,589 & 0,000 & valid \\
\hline & $X_{2.2}$ & 0,428 & 0,000 & valid \\
\hline & $X_{2.3}$ & 0,747 & 0,000 & valid \\
\hline & $X_{2.4}$ & 0,540 & 0,000 & valid \\
\hline & $X_{2.5}$ & 0,680 & 0,000 & valid \\
\hline & $X_{2.6}$ & 0,631 & 0,000 & valid \\
\hline & $X_{2.7}$ & 0,621 & 0,000 & valid \\
\hline & $X_{2.8}$ & 0,534 & 0,000 & valid \\
\hline & $X_{2.9}$ & 0,651 & 0,000 & valid \\
\hline & $X_{2.10}$ & 0,644 & 0,000 & valid \\
\hline & $X_{2.11}$ & 0,722 & 0,000 & valid \\
\hline Komitmen & $Y_{1}$ & 0,702 & 0,000 & valid \\
\hline \multirow[t]{5}{*}{ Organisasional $(Y)$} & $Y_{2}$ & 0,664 & 0,000 & valid \\
\hline & $Y_{3}$ & 0,531 & 0,000 & valid \\
\hline & $Y_{4}$ & 0,724 & 0,000 & valid \\
\hline & $Y_{5}$ & 0,626 & 0,000 & valid \\
\hline & $Y_{6}$ & 0,756 & 0,000 & valid \\
\hline
\end{tabular}

Tabel 1 menunjukkan bahwa hasil uji validitas dari seluruh variabel memiliki nilai signifikansi korelasi pearson product moment $<0,05$, sehingga itemitem pernyataan yang mengukur variabel penelitian dinyatakan valid. Uji reliabilitas dilakukan untuk menguji kehandalan kuesioner dalam mengukur variabel penelitian dengan menghasilkan pengukuran yang konsisten. Teknik yang digunakan adalah uji Cronbach's Alpha. Item-item pernyataan dalam kuesioner dinyatakan reliabel jika nilai Cronbach's Alpha > 0,6.
Tabel 2

Uji Reliabilitas

\begin{tabular}{lccc}
\hline \multicolumn{1}{c}{ Variabel } & $\begin{array}{c}\text { Cronbach's } \\
\text { Alpha }\end{array}$ & $\begin{array}{c}\text { Nilai } \\
\text { Kritis }\end{array}$ & Keterangan \\
\hline Motivasi Kerja $\left(\mathrm{X}_{1}\right)$ & 0,855 & 0,6 & reliabel \\
Kepuasan Kerja $\left(X_{2}\right)$ & 0,834 & 0,6 & reliabel \\
Komitmen Organisasional & 0,738 & 0,6 & reliabel \\
$(Y)$ & & & \\
\hline
\end{tabular}

Tabel 2 menunjukkan variabel motivasi kerja, kepuasan kerja dan komitmen organisasional memiliki nilai Cronbach's Alpha > 0,6, sehingga item-item pernyataan yang mengukur variabel penelitian dinyatakan reliabel. Pada analisis deskriptif akan dijelaskan gambaran profil responden penelitian serta jawaban responden pada masing-masing variabel penelitian.

Tabel 3

Deskriptif Profil Responden Berdasarkan Usia

\begin{tabular}{ccc}
\hline Usia & Frekuensi & Persentase $(\%)$ \\
\hline 21-30 tahun & 42 & 29,0 \\
31-40 tahun & 73 & 50,3 \\
41-50 tahun & 29 & 20,0 \\
51-60 tahun & 1 & 0,7 \\
\hline Total & 145 & 100,0 \\
\hline
\end{tabular}

Berdasarkan Tabel 3 diketahui mayoritas responden adalah karyawan berusia 31-40 tahun yaitu 73 orang $(50,3 \%)$, karyawan berusia $21-30$ tahun ada 42 orang (29\%), karyawan berusia 41-50 tahun ada 29 orang (20\%), sedangkan karyawan berusia 51-60 tahun hanya 1 orang $(0,7 \%)$. Hasil ini memberikan informasi bahwa sebagian besar responden adalah berusia 31-40 tahun dengan total responden sebanyak 73 orang.

Tabel 4

Deskriptif Profil Responden Berdasarkan Lama Kerja

\begin{tabular}{ccc}
\hline Lama Kerja & Frekuensi & Persentase $(\%)$ \\
\hline 5-10 tahun & 119 & 82,1 \\
$11-15$ tahun & 23 & 15,9 \\
$16-20$ tahun & 3 & 2,1 \\
\hline Total & 145 & 100,0 \\
\hline
\end{tabular}

Berdasarkan Tabel 4 diketahui mayoritas responden adalah karyawan yang memiliki lama kerja 5-10 tahun yaitu 119 orang $(82,1 \%)$, karyawan yang memiliki lama kerja 11-15 tahun ada 23 orang $(15,9 \%)$, sedangkan karyawan yang memiliki lama kerja 16-20 tahun hanya tiga orang $(2,1 \%)$. Hasil ini memberikan informasi bahwa sebagian besar responden adalah karyawan yang memiliki lama kerja 5-10 tahun dengan total responden sebanyak 119 orang. 
Deskriptif jawaban responden dilakukan dengan menghitung mean jawaban responden dan selanjut- nya mean jawaban responden dikategorikan sesuai dengan kriteria yang ditetapkan.

Tabel 5

Deskriptif Jawaban Responden pada Variabel Motivasi Kerja

\begin{tabular}{|c|c|c|c|c|c|c|c|c|}
\hline \multirow[t]{2}{*}{ Item } & \multirow[t]{2}{*}{ Pernyataan } & \multicolumn{5}{|c|}{ Frekuensi } & \multirow[t]{2}{*}{ Mean } & \multirow[t]{2}{*}{ Ket. } \\
\hline & & STS & TS & $\mathrm{N}$ & $\mathrm{S}$ & SS & & \\
\hline$X_{1 . I}$ & Saya tidak pernah bolos bekerja & 32 & 63 & 33 & 16 & 1 & 2,25 & Rendah \\
\hline & Saya taat pada peraturan kerja dalam organisasi & 3 & 51 & 77 & 12 & 2 & 2,72 & Rendah \\
\hline & $\begin{array}{l}\text { Saya memiliki relasi yang baik dengan rekan } \\
\text { kerja }\end{array}$ & 0 & 16 & 80 & 42 & 7 & 3,28 & Tinggi \\
\hline \multicolumn{7}{|c|}{ Arah Perilaku (Direction of Behavior) } & 2,75 & Rendah \\
\hline$X_{1.4}$ & Saya serius dalam bekerja & 3 & 45 & 68 & 27 & 2 & 2,86 & Rendah \\
\hline$X_{1.5}$ & Saya efisien dalam bekerja & 1 & 15 & 87 & 38 & 4 & 3,20 & Tinggi \\
\hline$X_{1.6}$ & Saya efektif dalam bekerja & 1 & 18 & 90 & 31 & 5 & 3,14 & Tinggi \\
\hline$X_{1.7}$ & Saya terampil dalam bekerja & 0 & 20 & 80 & 36 & 9 & 3,23 & Tinggi \\
\hline \multicolumn{7}{|c|}{ Tingkat Usaha (Level of Effort) } & 3,11 & Tinggi \\
\hline$X_{1.8}$ & $\begin{array}{l}\text { Saya pantang menyerah atau tidak mudah putus } \\
\text { asa }\end{array}$ & 0 & 17 & 82 & 36 & 10 & 3,27 & Tinggi \\
\hline$X_{1.9}$ & $\begin{array}{l}\text { Saya memiliki kegigihan dalam bekerja walau- } \\
\text { pun keadaan lingkungan kurang mendukung }\end{array}$ & 2 & 37 & 82 & 21 & 3 & 2,90 & Rendah \\
\hline$X_{1.10}$ & $\begin{array}{l}\text { Saya memiliki inisiatif untuk memecahkan ma- } \\
\text { salah }\end{array}$ & 1 & 19 & 89 & 26 & 10 & 3,17 & Tinggi \\
\hline$X_{1.11}$ & $\begin{array}{l}\text { Saya memiliki konsistensi yang tinggi dalam } \\
\text { bekerja (endurance) }\end{array}$ & 2 & 33 & 86 & 24 & 0 & 2,91 & Rendah \\
\hline \multirow{2}{*}{\multicolumn{7}{|c|}{$\begin{array}{l}\text { Tingkat Kegigihan (Level of Persistence) } \\
\text { Motivasi Kerja }\left(X_{J}\right)\end{array}$}} & 3,06 & Tinggi \\
\hline & & & & & & & 2,97 & Rendah \\
\hline
\end{tabular}

Tabel 6

Deskriptif Jawaban Responden pada Variabel Kepuasan Kerja

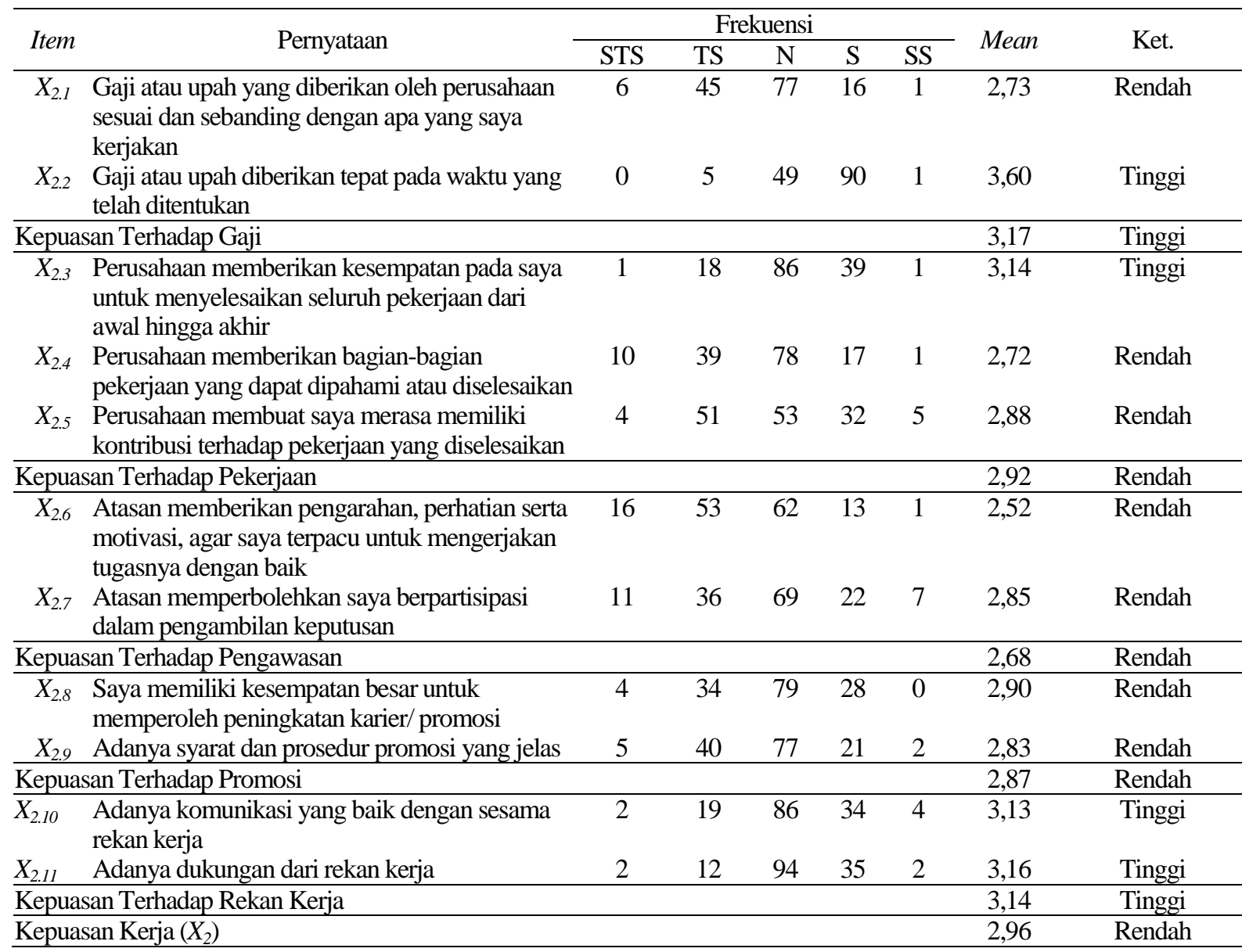


Tabel 7

Deskriptif Jawaban Responden pada Variabel Komitmen Organisasional

\begin{tabular}{|c|c|c|c|c|c|c|c|c|}
\hline \multirow{2}{*}{ Item } & \multirow{2}{*}{ Pernyataan } & \multicolumn{5}{|c|}{ Frekuensi } & \multirow{2}{*}{ Mean } & \multirow{2}{*}{ Ket. } \\
\hline & & STS & TS & $\mathrm{N}$ & $\mathrm{S}$ & SS & & \\
\hline$Y_{1}$ & Saya bangga menjadi bagian dari perusahaan & 4 & 28 & 77 & 29 & 7 & 3,05 & Tinggi \\
\hline & Saya merasa nyaman dengan nilai-nilai organisasi & 12 & 37 & 59 & 35 & 2 & 2,85 & Rendah \\
\hline \multicolumn{7}{|c|}{ Kebanggaan Terhadap Perusahaan } & 2,95 & Rendah \\
\hline$Y_{3}$ & $\begin{array}{l}\text { Saya menerima dan melakukan semua peraturan } \\
\text { yang berlaku di perusahaan }\end{array}$ & 24 & 49 & 45 & 22 & 5 & 2,55 & Rendah \\
\hline$Y_{4}$ & Saya melaksanakan setiap tugas yang diberikan & 3 & 39 & 59 & 42 & 2 & 3,01 & Tinggi \\
\hline \multicolumn{7}{|c|}{ Kesediaan Untuk Berpihak/Berkorban Bagi Perusahaan } & 2,78 & Rendah \\
\hline$Y_{5}$ & Saya ingin terus menjadi bagian dari perusahaan & 4 & 33 & 74 & 28 & 6 & 2,99 & Rendah \\
\hline$Y_{6}$ & $\begin{array}{l}\text { Saya merasa bahwa nilai-nilai yang ada dalam } \\
\text { organisasi sesuai dengan apa yang diyakini }\end{array}$ & 1 & 38 & 75 & 24 & 7 & 2,99 & Rendah \\
\hline \multicolumn{7}{|c|}{ Kesetiaan Terhadap Perusahaan } & 2,99 & Rendah \\
\hline \multicolumn{7}{|c|}{ Komitmen Organisasional $(Y)$} & 2,91 & Rendah \\
\hline
\end{tabular}

Berdasarkan Tabel 5 terlihat bahwa secara keseluruhan motivasi kerja karyawan yang menjadi responden penelitian tergolong rendah dengan mean jawaban sebesar 2,97. Motivasi kerja paling rendah adalah dalam hal arah perilaku (direction of behavior) dengan mean jawaban sebesar 2,75, sedangkan motivasi kerja paling tinggi adalah dalam hal tingkat usaha (level of effort) dengan mean jawaban sebesar 3,11 . Rendahnya arah perilaku pada karyawan perusahaan ini dapat menimbulkan motivasi kerja yang rendah pula karena karyawan merasa kurang termotivasi akan cenderung melakukan hal-hal yang kurang diinginkan.

Berdasarkan Tabel 6 terlihat bahwa secara keseluruhan kepuasan kerja karyawan yang menjadi responden penelitian tergolong rendah dengan mean jawaban sebesar 2,96. Kepuasan kerja paling rendah adalah dalam hal kepuasan terhadap pengawasan dengan mean jawaban sebesar 2,68 sedangkan kepuasan kerja paling tinggi adalah dalam hal kepuasan terhadap gaji dengan mean jawaban sebesar 3,17. Hal ini terjadi karena adanya pengawasan yang terbilang sangat ketat daripada atasan perusahaan terhadap karyawan perusahaan mengenai perubahan sistem yang lebih ketat dan adanya perubahan jam masuk karyawan, sehingga karyawan perusahaan merasa kurang puas dengan semua perubahan peraturan tersebut.

Berdasarkan Tabel 7 terlihat bahwa secara keseluruhan komitmen organisasional karyawan perusahaan yang menjadi responden penelitian tergolong rendah dengan mean jawaban sebesar 2,91. Komitmen organisasional paling rendah adalah dalam hal kesediaan untuk berpihak/berkorban bagi perusahaan dengan mean jawaban sebesar 2,78, sedangkan komitmen organisasional paling tinggi adalah dalam hal kesetiaan terhadap perusahaan dengan mean jawaban sebesar 2,99. Dari hasil tersebut dapat disimpulkan apabila motivasi kerja dan kepuasan kerja karyawan rendah, maka komitmen organisasional juga cenderung akan rendah pula.

Pendeteksian normalitas residual dilakukan dengan normal probability plot. Jika titik-titik pada normal probability plot terkumpul di sekitar garis lurus, maka disimpulkan residual model regresi berdistribusi normal. Hasil uji normalitas residual dengan normal probability plot, selanjutnya diperkuat dengan uji kolmogorov smirnov. Jika nilai signifikansi uji kolmogorov smirnov $>0,05(\alpha=5 \%)$, maka residual model regresi berdistribusi normal.

Dependent Variable: Komitmen Organisasional (Y)

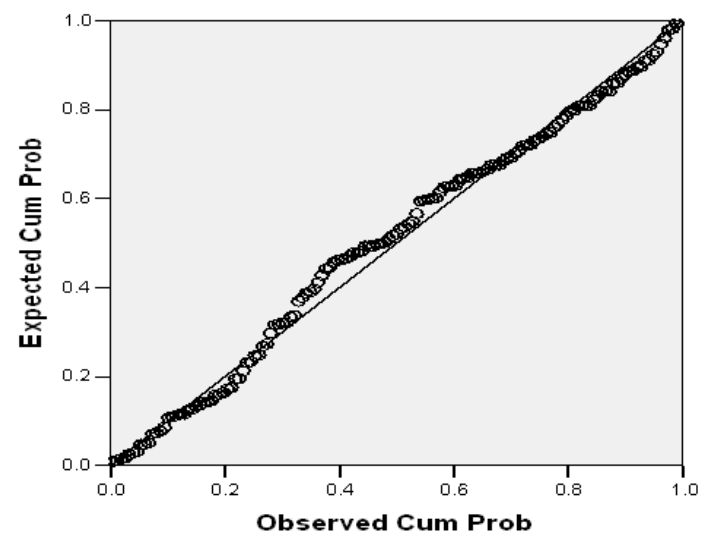

Gambar 2. Uji Normalitas dengan Normal Probability Plot

Dari Gambar 2 diketahui bahwa titik-titik terkumpul di sekitar garis lurus, sehingga disimpulkan residual model regresi mengikuti distribusi normal.

Tabel 8

Uji Normalitas dengan Uji Kolmogorov Smirnov

\begin{tabular}{lc}
\hline & Unstandardized Residual \\
\hline Kolmogorov Smirnov Z & 0,843 \\
Nilai Signifikansi & 0,475 \\
\hline
\end{tabular}


Tabel 8 menunjukkan bahwa besarnya nilai signifikan uji kolmogorov smirnov sebesar 0,475 > 0,05, maka dapat disimpulkan residual model regresi berdistribusi normal.

Multikolinieritas menunjukkan terjadinya korelasi yang kuat antara variabel bebas dalam model regresi. Analisis regresi mengansumsikan tidak ada multikolinieritas dalam model. Berikut adalah hasil uji multikolinieritas.

Tabel 9

Uji Multikoliniearitas

\begin{tabular}{lcc}
\hline \multicolumn{1}{c}{ Variabel } & Tolerance & VIF \\
\hline Motivasi Kerja $\left(\mathrm{X}_{1}\right)$ & 0,477 & 2,096 \\
Kepuasan Kerja $\left(X_{2}\right)$ & 0,477 & 2,096 \\
\hline
\end{tabular}

Tabel 9 menunjukkan nilai tolerance variabel motivasi kerja dan kepuasan kerja keduanya $>0,1$. Demikian pula VIF keduanya $<10$, sehingga disimpulkan tidak ada multikoliniearitas dalam model regresi.

Uji heteroskedastisitas dilakukan untuk mendeteksi ada tidaknya ketidakhomogenan ragam antar residual. Pendeteksian ada tidaknya heteroskedastisitas dilakukan dengan scatterplot dan korelasi rank spearman. Berikut adalah hasil uji heteroskedastisitas dengan korelasi rank spearman.

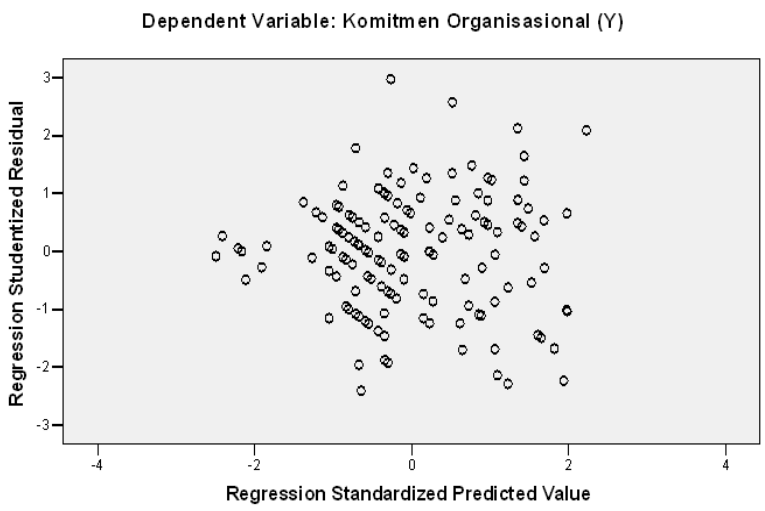

Gambar 3. Uji Heteroskedastisitas dengan Scatter Plot

Gambar 3 menunjukkan titik-titik tidak membentuk pola tertentu dan titik-titik menyebar di atas dan di bawah angka nol pada sumbu $Y$, sehingga dapat disimpulkan tidak terjadi heteroskedastisitas dalam model regresi.

\section{Tabel 10}

Uji Heteroskedastisitas dengan Korelasi Rank Spearman

\begin{tabular}{ccc}
\hline Variabel & Korelasi Rank Spearman & Sig. \\
\hline Motivasi Kerja $\left(\mathrm{X}_{1}\right)$ & 0,041 & 0,620 \\
Kepuasan Kerja $\left(X_{2}\right)$ & 0,031 & 0,710 \\
\hline
\end{tabular}

Tabel 10 menunjukkan nilai signifikansi korelasi rank spearman variabel motivasi kerja dan kepuasan kerja keduanya $>0,05$, maka disimpulkan dalam model regresi tidak ada heteroskedastisitas.

Dari nilai unstandardized coefficient $(B)$ yang dihasilkan analisis regresi diperoleh persamaan regresi sebagai berikut:

$$
Y=0,067+0,386 X_{1}+0,570 X_{2}
$$

Nilai konstanta sebesar 0,067 , artinya jika motivasi kerja dan kepuasan kerja sama dengan nol (tidak memberikan pengaruh), maka komitmen organisasional perusahaan adalah sebesar 0,067 . Hal ini berarti meskipun motivasi kerja dan kepuasan kerja tidak memberikan pengaruh, komitmen organisasional perusahan tetap ada karena adanya pengaruh faktor lain selain motivasi kerja dan kepuasan kerja.

Nilai koefisien regresi motivasi kerja $\left(X_{I}\right)$ sebesar 0,386, artinya jika motivasi kerja berubah satu satuan, maka komitmen organisasional akan berubah sebesar 0,386 dengan anggapan kepuasan kerja tetap (konstan). Tanda positif pada nilai koefisien regresi melambangkan hubungan yang searah antara motivasi kerja dan komitmen organisasional, artinya apabila motivasi kerja meningkat, maka komitmen organisasional perusahaan akan mengalami peningkatan.

Nilai koefisien regresi kepuasan kerja $\left(X_{2}\right)$ sebesar 0,570 artinya jika kepuasan kerja terjadi kenaikan, maka komitmen organisasional akan berubah sebesar 0,570 dengan anggapan motivasi kerja tetap (konstan). Tanda positif pada nilai koefisien regresi melambangkan hubungan yang searah antara kepuasan kerja dan komitmen organisasional, artinya apabila kepuasan kerja meningkat, maka komitmen organisasional perusahaan akan mengalami peningkatan. Uji $F$ digunakan untuk mengetahui pengaruh secara serempak (simultan) variabel bebas terhadap variabel terikat. Hasil uji $F$ seperti pada Tabel 11.

\section{Tabel 11}

Uji $F$

\begin{tabular}{lccccc}
\hline \multicolumn{1}{c}{ Model } & $\begin{array}{c}\text { Sum of } \\
\text { Squares }\end{array}$ & df & $\begin{array}{c}\text { Mean } \\
\text { Square }\end{array}$ F hitung & Sig. \\
\hline Regression & 25,325 & 2 & 12,663 & 75,964 & 0,000 \\
Residual & 23,670 & 142 & 0,167 & & \\
Total & 48,995 & 144 & & & \\
\hline
\end{tabular}

Berdasarkan Tabel 11 hasil uji $F$ diperoleh $F$ hitung sebesar 75,964 > F tabel 3,060 $\left(d f_{1}=2, d f_{2}=142\right.$, $\alpha=0,05$ ), dengan nilai signifikansi sebesar $0,000<$ 0,05 , maka $H_{0}$ ditolak dan disimpulkan motivasi kerja dan kepuasan kerja secara serempak berpengaruh signifikan terhadap komitmen organisasional perusahaan. 
Tabel 12

\section{Koefisien Determinasi}

\begin{tabular}{cc}
\hline$R$ & $R^{2}$ \\
\hline 0,850 & 0,517 \\
\hline
\end{tabular}

Berdasarkan Tabel 12 diketahui koefisien determinasi ( $R$ Square) yang diperoleh sebesar 0,517 menunjukkan bahwa kemampuan motivasi kerja dan kepuasan kerja dalam menjelaskan variasi perubahan komitmen organisasional perusahaan adalah sebesar $51,7 \%$ dan sisanya $48,3 \%$ dijelaskan oleh faktor lain. Berdasarkan hasil ini $\mathrm{H}_{3}$ yang menduga motivasi kerja dan kepuasan kerja karyawan memiliki pengaruh secara serempak dan positif terhadap komitmen organisasional dapat diterima.

Uji $t$ digunakan untuk mengetahui pengaruh secara parsial variabel bebas terhadap variabel terikat. Hasil uji $t$ adalah sebagai berikut:

\section{Tabel 13}

Uji $t$

\begin{tabular}{lccccc}
\hline Variabel Bebas & $B$ & $\begin{array}{c}\text { Std. } \\
\text { Error }\end{array}$ & Beta & $\begin{array}{c}t \\
\text { hitung }\end{array}$ & Sig. \\
\hline Konstanta & 0,067 & 0,233 & & 0,288 & 0,774 \\
Motivasi Kerja $\left(\mathrm{X}_{1}\right)$ & 0,386 & 0,103 & 0,317 & 3,756 & 0,000 \\
Kepuasan Kerja $\left(X_{2}\right)$ & 0,570 & 0,106 & 0,455 & 5,394 & 0,000 \\
\hline
\end{tabular}

Uji $t$ pengaruh motivasi kerja terhadap komitmen organisasional menghasilkan $t$ hitung sebesar $3,756>t$ tabel 1,656 $(d f=142, \alpha=0,05)$ dengan nilai signifikansi sebesar $0,000<0,05$, maka $H_{0}$ ditolak dan diputuskan motivasi kerja berpengaruh signifikan terhadap komitmen organisasional. Berdasarkan hasil ini $H_{l}$ yang menduga motivasi kerja karyawan memiliki pengaruh positif terhadap komitmen organisasional dapat diterima.

Uji $t$ pengaruh kepuasan kerja terhadap komitmen organisasional menghasilkan $t$ hitung sebesar $5,394>t$ tabel 1,656 $(d f=142, \alpha=0,05)$ dengan nilai signifikansi sebesar $0,000<0,05$, maka $H_{0}$ ditolak dan diputuskan kepuasan kerja berpengaruh signifikan terhadap komitmen organisasional. Berdasarkan hasil ini $H_{2}$ yang menduga kepuasan kerja karyawan memiliki pengaruh positif terhadap komitmen organisasional dapat diterima.

\section{Tabel 14}

\section{Koefisien Determinasi Parsial}

\begin{tabular}{lcc}
\hline Variabel & $r$ & $r^{2}$ \\
\hline Motivasi Kerja $\left(X_{1}\right)$ & 0,301 & 0,090 \\
Kepuasan Kerja $\left(X_{2}\right)$ & 0,412 & 0,170 \\
\hline
\end{tabular}

Dilihat dari nilai koefisien determinasi parsial $\left(r^{2}\right)$ pada Tabel 14 di antara motivasi kerja dan kepuasan kerja, variabel yang mempunyai pengaruh dominan terhadap komitmen organisasional adalah kepuasan kerja dengan nilai $r^{2}$ lebih besar yaitu 0,17 atau $17 \%$.

Analisis crosstab dilakukan untuk mengetahui profil responden dengan variabel motivasi kerja, kepuasan kerja, dan komitmen organisasional. Hasil crosstab dijelaskan pada Tabel 15,

\section{Tabel 15}

Crosstab antara Profil Responden dengan Motivasi Kerja

\begin{tabular}{|c|c|c|c|c|c|c|c|}
\hline \multirow{2}{*}{\multicolumn{2}{|c|}{ Profil Responden }} & \multicolumn{6}{|c|}{ Motivasi Kerja } \\
\hline & & \multicolumn{2}{|c|}{ Rendah } & \multicolumn{2}{|c|}{ Tinggi } & \multicolumn{2}{|c|}{ Total } \\
\hline & & $F$ & $\%$ & $F$ & $\%$ & $F$ & $\%$ \\
\hline \multirow[t]{4}{*}{ Usia } & 20-30 tahun & 19 & 45,2 & 23 & 54,8 & 42 & 100 \\
\hline & $31-40$ tahun & 42 & 57,5 & 31 & 42,5 & 73 & 100 \\
\hline & 41-50 tahun & 22 & 75,9 & 7 & 24,1 & 29 & 100 \\
\hline & $51-6$ & 0 & 0 & 1 & 100 & 1 & 100 \\
\hline Lama & $5-10$ tahun & 62 & 52,1 & 57 & 47,9 & 119 & 100 \\
\hline \multirow[t]{2}{*}{ Bekerja } & 11-15 tahun & 18 & 78,3 & 5 & 21,7 & 23 & 100 \\
\hline & 16-20 tahun & 3 & 100 & 0 & 0 & 3 & 100 \\
\hline
\end{tabular}

Tabel 15 menunjukkan bahwa motivasi kerja yang paling rendah terdapat pada karyawan yang berusia 41-50 tahun dengan lama bekerja 16-20 tahun. Hal ini dikarenakan karyawan yang telah bekerja antara 16-20 tahun mempunyai pengalaman kerja yang cukup lama dan telah memahami berbagai situasi yang ada di tempat bekerja. Motivasi kerja yang paling tinggi terdapat pada karyawan yang berusia 5160 tahun dengan lama bekerja 5-10 tahun. Hal ini dikarenakan karyawan pada usia ini belum memiliki pengalaman kerja yang cukup banyak, sehingga motivasi kerjanya tinggi.

Tabel 16

Crosstab Antara Profil Responden dengan Kepuasan Kerja

\begin{tabular}{lccccccc}
\hline & \multicolumn{6}{c}{ Kepuasan Kerja } \\
\cline { 3 - 8 } Profil Responden & \multicolumn{3}{c}{ Rendah } & \multicolumn{3}{c}{ Tinggi } & \multicolumn{2}{c}{ Total } \\
\cline { 3 - 8 } & & $F$ & $\%$ & $F$ & $\%$ & $F$ & $\%$ \\
\hline Usia & $20-30$ tahun & 19 & 45,2 & 23 & 54,8 & 42 & 100 \\
& $31-40$ tahun & 40 & 54,8 & 33 & 45,2 & 73 & 100 \\
& $41-50$ tahun & 18 & 62,1 & 11 & 37,9 & 29 & 100 \\
& $51-60$ tahun & 0 & 0 & 1 & 100 & 1 & 100 \\
Lama & $5-10$ tahun & 60 & 50,4 & 59 & 49,6 & 119 & 100 \\
Bekerja & $11-15$ tahun & 14 & 60,9 & 9 & 39,1 & 23 & 100 \\
& $16-20$ tahun & 3 & 100 & 0 & 0 & 3 & 100 \\
\hline
\end{tabular}

Tabel 16 menunjukkan bahwa kepuasan kerja yang paling rendah terdapat pada karyawan yang berusia 41-50 tahun dengan lama bekerja 16-20 tahun. Hal ini dikarenakan karyawan yang telah bekerja antara 16-20 tahun sudah merasakan perubahan yang 
terjadi pada perusahaan dan perubahan tersebut bersifat sepihak atau hanya menguntungkan perusahaan. Kepuasan kerja yang paling tinggi terdapat pada karyawan yang berusia 51-60 tahun dengan lama bekerja 5-10 tahun. Hal ini dikarenakan karyawan belum memiliki pengalaman kerja yang cukup banyak, sehingga kepuasan kerjanya tinggi.

Tabel 17

Crosstab Antara Profil Responden dengan Komitmen Organisasional

\begin{tabular}{lccccccc}
\hline \multirow{2}{*}{ Profil Responden } & \multicolumn{4}{c}{ Komitmen Organisasional } \\
\cline { 3 - 8 } & & \multicolumn{2}{c}{ Rendah } & \multicolumn{2}{c}{ Tinggi } & \multicolumn{2}{c}{ Total } \\
\cline { 3 - 8 } & $F$ & $\%$ & $F$ & $\%$ & $F$ & $\%$ \\
\hline Usia & $20-30$ tahun & 21 & 50 & 21 & 50,0 & 42 & 100 \\
& $31-40$ tahun & 41 & 56,2 & 32 & 43,8 & 73 & 100 \\
& $41-50$ tahun & 17 & 58,6 & 12 & 41,4 & 29 & 100 \\
& $51-60$ tahun & 0 & 0 & 1 & 100 & 1 & 100 \\
Lama & $5-10$ tahun & 66 & 55,5 & 53 & 44,5 & 119 & 100 \\
Bekerja & $11-15$ tahun & 12 & 52,2 & 11 & 47,8 & 23 & 100 \\
& $16-20$ tahun & 1 & 33,3 & 2 & 66,7 & 3 & 100 \\
\hline
\end{tabular}

Tabel 17 menunjukkan bahwa komitmen yang paling rendah terdapat pada karyawan yang berusia 41-50 tahun dengan lama bekerja 5-10 tahun. Hal ini dikarenakan karyawan pada usia 41-50 telah dibuktikan pada Tabel 16 dan 17 tidak memiliki motivasi dan kepuasan dalam bekerja yang tinggi. Lama bekerja 5-10 tahun juga belum cukup memiliki komitmen organisasional. Komitmen organisasional yang paling tinggi terdapat pada karyawan yang berusia 51-60 tahun dengan lama bekerja 16-20 tahun. Hal ini dibuktikan pada Tabel 16 dan 17. Usia 51-60 tahun memiliki motivasi dan kepuasan kerja yang paling tinggi dan telah bekerja cukup lama, sehingga memiliki komitmen organisasional yang tinggi.

Hasil penelitian ini telah mendukung penelitian Muhadi (2007) yang menyatakan bahwa kepuasan kerja berpengaruh positif signifikan terhadap komitmen organisasional. Mendukung penelitian Buraidah dan Waluyo (2002) yang menyatakan bahwa motivasi kerja mempunyai pengaruh terhadap komitmen organisasional, serta mendukung penelitian Sutanto dan Tania (2013) yang telah menyatakan bahwa motivasi kerja dan kepuasan kerja secara bersama-sama memiliki pengaruh positif dan signifikan terhadap komitmen organisasional karyawan.

Penelitian lain yang telah didukung oleh penelitian ini yaitu penelitian Brahmasari dan Suprayetno (2008) yang mengatakan bahwa motivasi kerja berpengaruh secara positif dan signifikan terhadap kepuasan kerja. Penelitian lainnya ialah oleh Kartika dan Kaihatu (2010) yang mengatakan bahwa motivasi kerja berpengaruh secara signifikan terhadap kepuas- an kerja karyawan. Selain itu juga penelitian Subyantoro (2009) yang mengatakan bahwa motivasi kerja berpengaruh langsung dan signifikan terhadap kepuasan kerja, penelitian Sudiro (2008) yang mengatakan bahwa kepuasan kerja berpengaruh pada komitmen organisasional, dan juga penelitian Sumarto (2009) yang mengatakan bahwa semakin tinggi kepuasan kerja ternyata diikuti oleh semakin tinggi komitmen organisasional.

\section{Simpulan}

Berdasarkan hasil analisis dan pembahasan, maka dapat disimpulkan hal-hal sebagai berikut: Nilai signifikansi pengaruh motivasi kerja terhadap komitmen organisasional sebesar 0,000 kurang dari 0,05 ( $\alpha$ $=5 \%$ ). Koefisien regresi motivasi kerja sebesar 0,386 menunjukkan bahwa variabel motivasi kerja berpengaruh positif dan signifikan terhadap komitmen organisasional karyawan perusahaan. Berdasarkan hasil ini, hipotesis pertama $\left(H_{l}\right)$ penelitian ini dapat diterima dan terbukti kebenarannya.

Nilai signifikansi pengaruh kepuasan kerja terhadap komitmen organisasional sebesar 0,000 kurang dari $0,05(\alpha=5 \%)$. Koefisien regresi kepuasan kerja sebesar 0,570 menunjukkan bahwa variabel kepuasan kerja berpengaruh positif dan signifikan terhadap komitmen organisasional karyawan perusahaan. Berdasarkan hasil ini, hipotesis kedua $\left(H_{2}\right)$ penelitian ini dapat diterima dan terbukti kebenarannya.

Nilai signifikansi pengaruh motivasi kerja dan kepuasan kerja terhadap komitmen organisasional sebesar 0,000 kurang dari 0,05 $(\alpha=5 \%)$, disimpulkan bahwa variabel motivasi kerja dan kepuasan kerja secara serempak berpengaruh signifikan terhadap komitmen organisasional karyawan perusahaan. Berdasarkan hasil ini, hipotesis ketiga $\left(H_{3}\right)$ penelitian ini dapat diterima dan terbukti kebenarannya. Terdapat faktor lain sebesar 48,3\% yang mempengaruhi komitmen organisasional karyawan perusahaan selain motivasi kerja dan kepuasan kerja.

\section{Daftar Referensi}

Brahmasari, I. \& Suprayetno, A. (2008). Pengaruh motivasi kerja, kepemimpinan dan budaya organisasi terhadap kepuasan kerja karyawan serta dampaknya pada kinerja perusahaan (Studi kasus pada PT Pei Hai International Wiratama Indonesia). Jurnal Manajemen dan Kewirausahaan, 10(2), 124-135.

Buraidah \& Waluyo, L. E. M. (2002). Pengaruh kompensasi dan motivasi kerja terhadap komitmen 
organisasi di organisasi pendidikan islam $x$. Diakses 23 Agustus 2012 dari http://www. Papers .gunadarma.ac.id/index.php/mpsi/.../15003.

Ghozali, I. (2012). Aplikasi analisis multivariate dengan program IBM SPSS. Semarang: Badan Penelitian Universitas Diponegoro.

Kartika, E. W. \& Kaihatu, T. S. (2010). Analisis pengaruh motivasi kerja terhadap kepuasan kerja (Studi kasus pada karyawan restoran di Pakuwon Food Festival Surabaya). Jurnal Manajemen dan Kewirausahaan, 12(1), 100-112.

Kuncoro, M. (2009). Metode riset untuk bisnis dan ekonomi. Jogjakarta: Erlangga.

Muhadi (2007). Analisis pengaruh kepuasan kerja terhadap komitmen organisasional dalam mempengaruhi kinerja karyawan. Unpublished undergraduated thesis, Universitas Diponegoro, Semarang.

Murti, H. \& Srimulyani, V. A. (2013). Pengaruh motivasi terhadap kinerja pegawai dengan variabel pemediasi kepuasan kerja pada PDAM Kota Madiun. Jurnal Riset Manajemen dan Akuntansi, 1(1), 10-17.
Panggalih, B. \& Zulaicha, R. (2012). Pengaruh kepuasan kerja terhadap organizational citizenship behavior dengan motivasi kerja sebagai variabel intervening pada karyawan PT Telkom Tegal. Performance, 16(2), 1-15.

Subyantoro, A. (2009). Karakteristik individu, karakteristik pekerjaan, karakteristik organisasi dan kepuasan yang dimediasi oleh motivasi kerja. Jurnal Aplikasi Manajemen, 11(1), 11-19.

Sudiro, A. (2008). Pengaruh komitmen keorganisasian dan kepuasan kerja terhadap kinerja tenaga edukatif/dosen (Studi di Universitas Brawijaya Malang). Jurnal Aplikasi Manajemen, 7(1), 8692.

Sugiyono (2011). Metode penelitian kuantitatif kualitatif dan $r \& d$. Bandung: Alfabeta.

Sumarto. 2009. Meningkatkan komitmen dan kepuasan untuk menyurutkan niat keluar. Jurnal Manajemen dan Kewirausahaan, 11(2), 116-125.

Sutanto, E. M. \& Tania, A. (2013). Pengaruh motivasi kerja dan kepuasan kerja terhadap komitmen organisasional karyawan PT Dai Knife di Surabaya. Agora, 1(3), 1-9. 